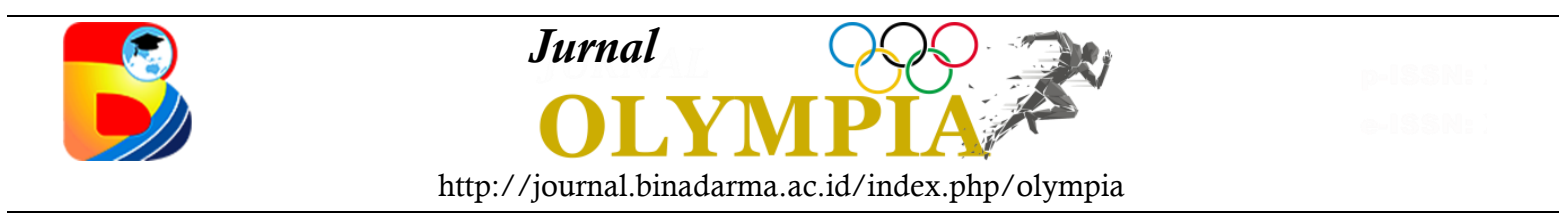

\title{
Pengaruh Latihan Kekuatan Otot Tungkai Terhadap Hasil Smash Peserta Ekstrakurikuler Bola Voli Pendidikan Olaharaga Universitas PGRI Palembang
}

\section{Daryono $^{1}$}

Universitas PGRI Palembang, Indonesia ${ }^{1}$

\section{Info Artikel}

Sejarah Artikel:

Diterima Januari 2019

Disetujui Februari 2019

Dipublikasikan Maret 2019

Keywords: leg muscle strength, smash, volleyball

\begin{abstract}
Abstrak
Tujuan dari penelitian ini adalah untuk mengetahui pengaruh latihan kekuatan otot tungkai terhadap hasil smash pada peserta ekstrakukikuler bola voli di Pendidikan Olahraga Universitas PGRI Palembang. Metode penelitian yang digunakan adalah metode eksperimen dengan jenis penelitian One-Group Pratest-Posttest. Sampel dalam penelitian ini berjumlah 20 orang yang mengikuti ekstrakulikuler bola voli di Universitas PGRI Palembang. Instrument tes yang digunakan yaitu tes smash. Teknik analisis data yang digunakan adalah uji-t. Hasil penelitian menunjukan bahwa hasil uji t diperoleh nilai t-hitung $(6,735)>\mathrm{t}$-tabel $(2,405)$, hasil tersebut diartikan Ha: diterima dan Ho: di tolak, sehingga dapat disimpulkan ada pengaruh siknifikan latihan kekuatan otot lengan terhadap hasil Kekuatan otot tungkai pada peserta ekstrakurikuler bola voli di Universitas PGRI Palembang, Pengaruh tersebut ditunjukan dengan meningkatnya kemampuan smash sebesar 30,35\%.
\end{abstract}

\begin{abstract}
The purpose of this study was to determine the effect of leg muscle strength training on smash results in volleyball extracurricular participants at the University of Palembang PGRI Sports Education. The research method used is the experimental method with the type of Pratest-Posttest One-Group research. The sample in this study were 20 people who participated in volleyball extracurricular activities at the University of PGRI Palembang. The test instrument used is the smash test. The data analysis technique used is the t-test. The results showed that the results of the $t$ test were obtained t-count (6,735)> t-table $(2,405)$, these results were interpreted Ha: accepted and Ho: rejected, so it can be concluded that there was a significant effect of the arm muscle strength training on the results of leg muscle strength in volleyball extracurricular members at the PGRI University of Palembang, the influence was shown by the increase in smash ability by $30.35 \%$.
\end{abstract}

Alamat korespondensi: J1. Jend Ahmad Yani, Lr. Gotong Royong, 9/10 Ulu, Seberang Ulu I, Kota Palembang, Sumatera Selatan 30116

Email: mrdary.ion@gmail.com 


\section{PENDAHULUAN}

Bola voli merupakan salah satu cabang olahraga permainan yang termasuk dalam materi pokok pendidikan jasmani olahraga dan kesehatan. Banyak manfaat yang diperoleh dengan bermain bola voli yang diantaranya adalah dapat membentuk sikap tubuh yang baik meliputi anatomis, fisiologis, kesehatan dan kemampun jasmani. Manfaatnya bagi rohani yaitu kejiwaan, kepribadian dan karakter akan tumbuh ke arah yang sesuai dengan tuntutan masyarakat.

Dalam kelompok pengembangan diri di sekolah terdapat dua kategori yaitu bidang bimbingan konseling dan bidang ekstrakurikuler. Kegiatan ekstrakurikuler yang ditawarkan masing-masing sekolah selain meningkatkan minat dan bakat siswa dalam bidang non-akademik, juga sebagai sarana aktivitas siswa yang positif sehingga siswa bisa semakin terhindar dari kegiatan yang merugikan. Melalui kegiatan ekstrakurikuler para siswa dapat lebih memiliki rasa percaya diri, belajar berorganisasi, bekerja sama dan memiliki rasa tanggung jawab pada sebuah kelompok. Semakin bervariasi kegiatan ekstrakurikuler yang ditawarkan oleh sebuah sekolah tentunya bervariatif pula minat siswa untuk dapat tertarik mengikuti salah satu kegiatan ekstrakurikuler tersebut.

Bola voli termasuk dalam ekstrakurikuler yang ada di Universitas PPGRI Palembang. Salah satu teknik dasar bola voli yang diajarkan di Universitas PPGRI Palembang adalah smash. smash adalah suatu pukulan yang kuat dimana tangan kontak dengan bola secara penuh pada bagian atas, sehingga jalannya bola terjal dengan kecepatan yang tinggi, apabila pukulan bola lebih tinggi berada diatas net, maka bola dapat dipukul ke bawah (M. Mariyanto, 2006 : 128).

Berdasarkan pengamatan dilapangan bahwa penguasaan teknik dasar bola voli siswa peserta ekstrakurikuler bola voli di Universitas PPGRI Palembang belum baik dan perlu ditingkatkan, terutama pada teknik smash. Berdasarkan pengamatan pada peserta ekstrakulikuler bola voli di Universitas PPGRI Palembang tidak jarang para siswa kurang mampu melakukan smash. Sering kali smash yang dilakukan menyangkut net atau tidak sampai ke lapangan lawan, dan kadang juga keluar dari daerah lawan. Karena kemampuan individu setiap peserta ekstrakulikuler berbeda dan bentuk latihan yang diberikan kurang mendukung dalam meningkatkan keterampilan smash, maka penelitian ini akan meneliti keterampilan smash.

Dalam meningkatkan hasil pukulan Smash diperlukan latihan yang teratur, dan sistematis yang mengarah pada ketepatan. Smash dilihat dari gerakan pada bagian tubuh, memerlukan kekuatan otot lengan yang sangat bagus. Dengan melatih kekuatan otot lengan pada siswa ekstrakulikuler bola voli di Universitas PPGRI Palembang diharapkan memiliki kemampuan pukulan Smash yang baik. Untuk menunjang hasil pukulan Smash bola voli, penelitian ini akan mengkaji tentang latihan kekuatan otot lengan. Mengapa hanya 
menggunakan latihan kekuatan otot lengan tersebut? dikarenakan bahwa latihan tersebut diduga berdasar analisis gerak berkaitan pada Smash bola voli.

Permasalahan yang telah dikemukakan di atas yang melatar belakangi judul penelitian Pengaruh latihan kekuatan otot lengan terhadap hasil pukulan Smash atas pada peserta ekstrakurikuler bola voli di Universitas PPGRI Palembang.

\section{METODE PENELITIAN}

Metode yang digunakan dalam penelitian adalah eksperimen. Rancangan penelitian yang digunakan dalam penelitian ialah One-Group Pretest-Posttest Design. Desain dilakukan dengan mengukur subjek penelitian (pretest) sebelum diadakannya perlakuan (treatment) dan melakukan pengukuran kembali setelah diberi perlakuan (posttest). Populasi penelitian adalah seluruh siswa peserta ekstrakurikuler bola voli Universitas PPGRI Palembang yang berjumlah 15 Orang. Karena populasi kurang dari 100, maka peneliti menggunakan teknik purposife sampling yaitu seluruh anggota populasi dijadikan sampel penelitian.

Dalam penelitian ini pengumpulan data dilakukan dengan menggunakan tes. Tes adalah "instrumen atau alat yang digunakan untuk memperoleh informasi tentang individu atau objek".

Tes Kekuatan otot tungkai
a. Tujuan

Untuk mengukur keterampilan dalam melakukan smash.

b. Alat dan perlengkapan.

1) Lapangan bolavoli ukuran normal lengkap dengan tiang dan net, dibuat garis-garis yang membatasi sasaran nilai.

2) Tinggi net $2,30 \mathrm{~m}$ untuk putra dan $2,15 \mathrm{~m}$ untuk putri

3) Bolavoli

c. Pelaksanaan

1) Testee berada dalam daerah serang atau bebas dilapangan permainan

2) Bola dilambungkan atau diumpan dekat atas jarring ke atas testee

3) Dengan atau awalan, testee meloncat dan memukul bola melampaui atas jarring kedalam lapangan diseberangnya dimana terdapat sasaran dengan angka-angka.

4) Stop watch dijalankan pada waktu bola tersentuh oleh tangan testee, dan dihentikan pada saat bola menyentuh lantai.

d. Cara Menskor :

Skor terdiri dari dua bagian yang tidak terpisahkan, yaitu angka sasaran pus waktu dari kecepatan jalannya bola.

1) Skor waktu dalam detik hingga persepuluhannya

2) Bola yang menyentuh batas sasaran, dihitung telah masuk sasaran dengan angka yang lebih besar

3) Skor $=0$, jika pemukul menyentuh jaringan dan atau jatuh di luar sasaran.Teknik analisis data merupakan suatu cara yang digunakan untuk memperoleh atau 
menganalisis data-data yang diperoleh. Analisis tersebut bertujuan untuk kebenaran hipotesis yang dirumuskan, suatu hipotesis akan diterima atau ditolak tergantung dari analisis data. Teknik analisis data statistik yang peneliti gunakan adalah t-test (uji-t).

\section{HASIL DAN PEMBAHASAN}

Hasil penelitian data pretest Kekuatan otot tungkai pada peserta ekstrakurikuler bolavoli di Universitas PPGRI Palembang diperoleh nilai minimal sebesar 13; nilai maksimal 20; rata-rata (mean) sebesar 15, nilai tengah (median) sebesar 12; modus sebesar 13; dan simpangan baku (standar deviasi) sebesar 2,45.

Tabel 1. Deskripsi Data Pretest

\begin{tabular}{lc}
\hline Uraian & Posttest \\
\hline Maksimal & 20 \\
Minimal & 13 \\
Rata-Rata & 15 \\
\hline
\end{tabular}

Hasil penelitian posttest Kekuatan otot tungkai pada peserta ekstrakurikuler bolavoli Universitas PPGRI Palembang diperoleh nilai minimal sebesar 17; nilai maksimal 27; ratarata (mean) sebesar 19, nilai tengah (median) sebesar 21; modus sebesar 19; dan simpangan baku (standar deviasi) sebesar 3,27.

Tabel 2. Deskripsi Data Pretest

\begin{tabular}{cc}
\hline Uraian & Posttest \\
\hline Maksimal & 27 \\
Minimal & 17 \\
Rata-Rata & 19 \\
\hline
\end{tabular}

Uji t dilakukan untuk mengetahui ada tidaknya pengaruh latihan beban terhadap hasil Kekuatan otot tungkai pada peserta ekstrakurikuler bolavoli Universitas PPGRI Palembang. Uji t hasilnya dapat dilihat pada tabel berikut:

Tabel 3. Hasil Uji Hipotesis (Uji t)

\begin{tabular}{|c|c|c|c|c|c|}
\hline $\begin{array}{c}\text { Pretest } \\
- \\
\text { Posttest }\end{array}$ & Df & $\begin{array}{c}\text { T- } \\
\text { tabel }\end{array}$ & $\begin{array}{c}\text { T- } \\
\text { hitung }\end{array}$ & P & Ket \\
\hline Smash & 19 & 2,405 & 6,735 & 0,00 & $\begin{array}{c}\text { Ada } \\
\text { Pengaruh }\end{array}$ \\
\hline
\end{tabular}

Dari hasil uji $\mathrm{t}$ tesebut diketahui nilai $\mathrm{t}$ hitung $(6,735)>t$ tabel $(2,405)$, dan nilai $\mathrm{p}$ (probabilitas) < dari 0,05. Hasil tersebut diartikan Ha: diterima dan Ho: di tolak, sehingga hipotesisnya menyatakan ada pengaruh latihan beban terhadap hasil Kekuatan otot tungkai pada peserta ekstrakurikuler bolavoli Universitas PPGRI Palembang.

\section{Pembahasan}

Smash adalah pukulan cepat dan keras yang di lakukan oleh seorang pemain bola voli ketika bola hasil umpan temannya melambung tinggi dan di pukul secara menukik dengan keras pada daerah lawan. Untuk memperoleh kemampuan Kekuatan otot tungkai yang baik seorang pemain harus di dukung oleh latihan agar pukulanya sampai pada daerah lawan dan mematikan, kelemahan dari Kekuatan otot tungkai biasanya seorang pemain yang tidak tidak mempunyai kekuatan otot tungkai tidak akan sampai dalam melintasi net dan bahkan 
mudah diterima oleh lawan. Untuk meningkatkan kekuatan otot lengan tersebut maka dapat dilakukan dengan metode latihan yang efektif salah satunya dengan metode latihan beban.

Metode latihan beban merupakan salah satu cara pemantapan kondisi yang melibatkan gerakan yang berulang-ulang dengan beban yang submaksimal. Dalam penelitian ini latihan yang digunakan adalah dengan latihan naik turun tangga, dan latihan beban.

Berdasarkan hasil penelitian di atas diperoleh nilai $\mathrm{t}$ hitung $(6,735)>\mathrm{t}$ tabel $(2,405)$. Hasil tersebut diartikan latihan beban member pengaruh terhadap hasil Kekuatan otot tungkai pada peserta ekstrakurikuler bolavoli Universitas PPGRI Palembang. Pengaruh tersebut ditunjukan dengan meningkatnya kemampuan Kekuatan otot tungkai sebesar 27,35\%. Peningkatkan bernilai positif yang artinya hasil servis setelah diberi metode latihan beban menjadi lebih baik.

Latihan naik turun tangga dan latihan beban dilakukan secara kontinyu berfungsi meningkatkan kinerja otot lengan, yang mana penambahan kinerja tersebut dapat menambah kekuatan otot tungkai, sehingga dengan bertambahnya kekuatan otot tungkai maka secara tidak langsung kemampuan siswa dalam melakukan Kekuatan otot tungkai dapat bertambah.

Kekuatan pada lengan sangatlah penting dikarenakan meningkatnya kekuatan dalam memukul bola akan memberikan jauhnya servis sehingga dapat melampaui net, dengan demikian siswa dapat mengarahkan bola lebih tepat sasaran, sesuai yang dinginkan. Ketepatan dalam penempatan bola menjadikan pemain mampu melakukan servis dengan menempatkan bola pada daerah yang sulit dijangkau lawan.

Selain itu untuk meningkatkan kemampuan servis ataas harus ditunjang dengan dengan frekuensi latihan yang terus menerus dan tetap melakukan pembelajaran Kekuatan otot tungkai dalam permainan bolavoli. Pembelajaran yang kontinyu secara otomatis akan meningkatkan intensitas latihan, yang mana dengan intensitas latihan banyak membiasakan siswa dalam melakukan servis. Latihan yang terus menerus menjadikan pemain mampu mengetahui kesalahakesalahan yang dibuat dalam servis, sehingga dengan demikian dapat diperbaiki yang mana menjadikan servis akan semakin baik.

\section{SIMPULAN}

Berdasarkan hasil analisis data dan pembahasan dapat disimpulkan ada pengaruh latihan kekuatan otot lengan yang signifikan terhadap hasil Kekuatan otot tungkai pada peserta ekstrakurikuler bolavoli Universitas PPGRI Palembang, Pengaruh tersebut ditunjukan dengan meningkatnya kemampuan Kekuatan otot tungkai sebesar $27,35 \%$.

Setiap metode pembelajaran memiliki efektivitas yang berbeda dalam meningkatkan kemampuan servis bolavoli. Oleh karena itu, dalam memberikan pembelajaran yang bertujuan 
untuk meningkatkan kemampuan Kekuatan otot tungkai bolavoli menerapkan metode pembelajaran yang tepat. Hasil penelitian ini dapat dijadikan dasar pertimbangan untuk memilih metode pembelajaran yang tepat, khususnya untuk meningkatkan kemampuan Kekuatan otot tungkai bolavoli.

\section{DAFTAR PUSTAKA}

Abdillah, Anang Qosim, Rubiyatno Rubiyatno. 2017. Pengaruh Latihan Kekuatan Otot Lengan Terhadap Kemampuan Kekuatan otot tungkai Dalam Permainan Bolavoli Mahasiswa Putra. Pontianak: Jurnal Pendidikan Olahraga. Vol.6, No.2 : 96-103.

Arikunto, Suharsimi. 2010. Prosedur Penelitian Suatu Pendekatan Praktik. Jakarta : Rineka Cipta.

Dieter Beutelstahl. 2008. Belajar Bermain Bola Volley. Bandung: Pioner Jaya.

Faruq, Muhammad Muhyi. 2009. Meningkatkan Kebugaran Jasmani Melalui Permainan dan Olahraga Bola Voli. Jakarta: Gramedia Widiasarana Indonesia.

Harsono. 2001. Coaching dan Aspek-Aspek Psikologis dam Coaching. Jakarta : Depdikbud.

Ismaryati. 2010. Tes dan Pengukuran Olahraga. Semarang : Universitas Sebelas Maret.

Mariyanto,M. Dkk, (2006). "Permainan Bola Besar II Bola Voli. Jakarta: Departemen Pendidikan dan Kebudayaan.
Nurhasan. 2001. Tes dan Pengukuran Dalam Pendidikan Jasmani, Prinsip-prinsip dan Penerapannya. Jakarta: Direktorat Jenderal Olahraga.

Sukadiyanto. 2005. Pengantar Teori Dan Metodelogi Melatih Fisik. Yogyakarta: FIK UNY.

Sukirno dan Waluyo. 2012. Cabang Olahraga Bola Voli. Palembang: Universitas Sriwjaya Press 